\title{
ISLAM AND THE THREE WAVES OF GLOBALISATION: THE SOUTHEAST ASIAN EXPERIENCE
}

\author{
Osman Bakar*
}

\begin{abstract}
This article is intended to comment on the civilisational history of Islam in Southeast Asia. The history is explained and accounted for in terms of the three major waves of globalisation that have impacted the region since the arrival of Islam as early as the eleventh century. The first wave, itself initiated and dominated by Islam, was responsible for the introduction and establishment of Islam in the region to the point of becoming its most dominant civilisation. The expansion of Islam and its civilisation was in progress when the second wave hit the shores of the MalayIndonesian Archipelago with the arrival of the Portuguese and other Western powers resulting in the colonisation of the region. The third wave, an American-dominated one, manifests itself in the post-colonial period which witnesses Southeast Asian Islam reasserting itself in various domains of public life. The author sees Southeast Asian Islam as the historical product of centuries-long civilisational encounters with the pre-Islamic indigenous cultures and civilisations and later between 'MalayIndonesian Islam' and the newly arriving religions and cultures brought by both the colonial and post-colonial West, arguing that Islam in the region has been significantly impacted by each of the three waves.
\end{abstract}

\section{Introduction ${ }^{1}$}

The main purpose of this article is to investigate and highlight on the multi-faceted relations between Islam as a religion and as a civilisation and the phenomenon of what is now popularly termed globalisation. In studying these relations I will not be looking at the whole of the Islamic world or the entire global Muslim community (ummah). ${ }^{2}$ Rather, I will be looking only at a - geographically speaking - small part of it, namely Southeast Asian Islam or more precisely, Islam in the Malay-speaking world of which modern Indonesia and Malaysia are the core members.

* Prof. Dr Osman Bakar is the Deputy CEO of the International Institute of Advanced Islamic Studies (IAIS) Malaysia. 
Culturally and in terms of civilisation, however, the Malay-Indonesian Archipelago, which is home to more than 220 million Muslims and thus to be appropriately regarded as the heartland of Southeast Asian Islam, is an important region to be reckoned with. For demographic and political-economic reasons alone, ${ }^{3}$ Southeast Asian Islam easily qualifies as a major geo-cultural branch of the global ummah and also as one of her most active and most strategic in international relations and politics. Given the region's strategic importance, political stability, well-planned economic development, and immense resources, both natural and human, many observers of Southeast Asian Islam believe that it stands a better chance than any other geo-cultural region of the Islamic world to play a decisive role in influencing and shaping the twenty-first-century Islam.

I am fully aware of the various shades of meanings given to the term 'globalisation'. These range from the narrowest which I identify with the "rapid growth of interdependency and connection in the world of trade and finance" to the broadest which I would like to equate with the cultural and civilisational process at the global level that at once puts into sharp focus both the common human culture and civilisation that unites the global community and the different cultures and civilisations that tend to divide it. In writing this article, given both my philosophical outlook and my commitment to the grand agenda of civilisational renewal (tajdìd al-hadiarr $\bar{l})^{5}$ conceived and actively pursued by the International Institute of Advanced Islamic Studies (IAIS) Malaysia to which I am currently attached, I am inclined to accept the most universal and the most comprehensive meaning of globalisation.

Rather than referring to globalisation merely as certain selected phenomena and processes in just one or two sectors of human life and thought, I am arguing here for a more comprehensive usage of the term globalisation so as to embrace phenomena and processes in other domains of human civilisation having the same natures and characteristics. This broad understanding of the term would also enable us to better identify antecedents to contemporary globalisations, if any, and even if these existed on a lesser scale compared to the later. In other words, there could have existed antecedent globalisations that deserve to be called globalisations insofar as these comply with the currently accepted definitions of the term.

Equally beneficial, the broad usage of the term would also enable us to have a more holistic view of global trends and changes in all domains of contemporary civilisation and thus also of the different global forces shaping them. This way, we would be able to have a more complete picture of globalisation and its multidimensional impact on contemporary civilisation, particularly of the way in which globalisation contributes to the enlargement of the civilisational space we humanity call 'our common civilisation' as well as to the sharpening of differences, both real and imagined, between the world's major cultures and civilisations. 
This article is essentially about the civilisational history of Southeast Asian Islam. ${ }^{6}$ The thesis presented in this article is that contemporary Southeast Asian Islam is basically the historical product of the encounters between different religions and civilisations that had gained footholds in the region. The Southeast Asian region in general is noted for its historical experience as the meeting point of the world's major religions and cultures. I seek to affirm this thesis through a study of the major waves of globalisation that have shaped and influenced Southeast Asian Islam throughout its history. The premise is that each major religion produces its own mini-globalisation. The more comprehensive globalisation that we witness today is not just the product of modern Western civilisation, let alone of Western Christianity only, but rather the joined contributions of all of the world's religions and cultures. Based on this premise, I seek to argue that it was the Islamic wave of globalisation originating from the heartland of Islam that had brought Islam to Southeast Asia in the first place and shaped its development.

The long historical encounter in the region between the new religion and the indigenous cultures and civilisations was in progress when another wave of globalisation hit the shores of the Archipelago. This was the series of European waves of globalisation that later led to the colonisation of the region, starting with the Portuguese wave which saw the invasion and capture of Malacca in 1511. These colonial waves had a major impact on the development of Southeast Asian Islam. These did not subside until after the Second World War which saw the end of Western colonialism in the region. Then there is the American-dominated post-colonial wave of globalisation which persists to this day. In this post-colonial era, however, Southeast Asian Islam under its newfound freedom begins to assert itself in numerous ways. The history of these three major waves of globalisation in the region, properly understood, could be of considerable help to those of us who seek to better understand contemporary Southeast Asian Islam, particularly Islam in Malaysia and in Indonesia.

\section{Clarifying the Key Terms}

Let me proceed with a further explanation of the key terms used in the title of this article. First, I would like to explain what I mean by the term 'Southeast Asian Islam'. By 'Southeast Asian Islam', I am referring to Islam as it has been understood and practised by Muslims in the region in the last eight centuries or so, leading to its contemporary culture and civilisation. This is predominantly the Sunnite branch of Islam. From the time of its establishment which I identify with the founding of the first Muslim state in the region in 1292 in Sumatra, Indonesia, until modern times the dominant theology in Southeast Asian Islam is Ash arism as mainly interpreted and articulated by Abū Ḥāmid al-Ghazālī, perhaps the most 
influential Muslim thinker in the Malay world. The dominant school of Islamic law is the Shāfi ite school of thought, which almost exclusively shapes the MalayIndonesian religious legal thought.

We are thus presented here with the first major characteristic of Southeast Asian Islam. This major branch of world Islam is, theologically and legally speaking, remarkably homogeneous by comparison with many other branches. Islam as a whole, in its global manifestations, is, however, far from monolithic. On the contrary, Islam is pluralistic in its interpretations and has a rich diversity, yet is united by common beliefs and religious practices and the spiritual bonds inherent in the idea of the global 'Muhammadan community' (ummah). Geographically speaking Southeast Asian Islam may be on the periphery of this global Muslim community, but for various reasons, not least the influence of the pilgrimage (hajj), it has always been conscious of its existence as an integral part of that single ummah. The religious homogeneity of Southeast Asian Islam has one important consequence. Muslims in the region are spared the kind of intra-religious strife and sectarianism that has befallen several Muslim countries.

About 230 million Muslims live in the whole of Southeast Asia, which consists of eleven nation-states that, with the exception of Timor-Leste, also make up the regional grouping known as ASEAN (Association of Southeast Asian Nations). The demographic figure means that the Muslims constitute the biggest religious group in the region followed by the Buddhists. Three of the nation-states - Indonesia, Malaysia, and Brunei Darussalam - have Muslim majorities. These countries together form the heartland of Southeast Asian Islam with about 200 million Muslims in Indonesia alone, making it the most populous Muslim country on earth.

Many Muslims in these three countries are ethnic Malays whose mother tongue is Malay and many speak Indonesian (which is closely related to Malay) as a lingua franca. In fact, except in Myanmar, many of the Muslim minorities in each of the other ASEAN countries are ethnically related to the Malays. In Myanmar, its Muslim minority is made up of ethnic Malays and other ethnic groups, particularly the Rohingyas of Bengali origin. In light of these facts, we may say that Southeast Asian Islam has a close affiliation with Malay culture. We shall see later that the Malay Diaspora is scattered not only in the inland Southeast Asia but also as far away as Madagascar, South Africa and even Surinam in Latin America.

\section{What is Globalisation?}

Although I have made a lot of references to the phenomenon of globalisation in the introduction, I have not yet explained the nature and characteristics of the phenomenon. The term 'globalisation' therefore needs further explanation. There is wide recognition that the term 'globalisation' is vague, ambiguous and theoretically 
contested. There are several understandings and definitions of the term. The most popular usage of the term limits its understanding to the economic domain, seeking to define or explain it in terms of certain or all of contemporary economic phenomena such as increasing shares of trade in GDP, the emergence of services trade and international finance as the most dynamic sector of international economic activity, and the virtues and vices of multinational firms. For those favouring such an understanding of the term, economic globalisation is globalisation as such. But others see theoretical legitimacy and practical reality in broadening the concept of globalisation to embrace other phenomena beyond the economic or politicaleconomic domain, a view which I share.

I would like to state here my position in a somewhat clearer manner. I am interested in understanding contemporary globalisation as a multi-dimensional phenomenon with historical antecedents. We may then speak of globalisation in its political dimension or simply political globalisation such as when we refer to the Westerninitiated globalisation of democracy, human rights, particularly women's rights, and governance. We may speak of socio-cultural globalisation such as when we refer to America's globalisation of Hollywood culture. We may also speak of scientific and technological globalisation such as when we refer to the globalisation of modern Western scientific culture and the globalisation of technological products such as information technology. Yet another is the religious dimension of globalisation such as when we refer to evangelical Christianity's global efforts to spread the Christian faith to the four corners of the globe.

My claim is that this multidimensional globalisation of our times has historical antecedents that take us as far back as to the tenth century. There are certain essential elements that go into our current understanding or definition of globalisation that appeared to be present as well in the global phenomena of earlier times, thus allowing us to speak of past globalisations. The manifested dimensions of earlier globalisations or the intensity of their global manifestations may not be the same or as powerful as our present experience of globalisation. But if we were to liken contemporary globalisation to a strong wave, then its historical antecedents correspond to perhaps much weaker waves. Nonetheless they are still waves!

Let me pose this very important question: What are the common essential elements and features of globalisation that will help us to understand it regardless of which of its dimensions we have in mind? To this question, I would answer that there are at least four such elements. First, there are common trends and processes of a global nature, pointing clearly to the interconnectedness of human activity on a global scale, the increasing interdependence of our world, and the spread of trans-border practices in various domains. Second, there are identifiable common forces, economic or otherwise, that shape or influence those trends and processes. Third, there are common objects, tangible or otherwise, associated with those trends 
and processes that are being globalised. And fourth, there are common goals sought to be achieved through the pursuit or opposition, manipulation and enhancement of those trends and processes.

It is in this context of our understanding of the multi-dimensional character of globalisation that I will be speaking of its three major waves. In the following discussion of these waves, it may be observed that most, if not all, of the defining elements of globalisation mentioned are present in each of the waves considered. However, my treatment of these waves of globalisation is pursued only insofar as they are relevant to our discussion of their impact on and interaction with Southeast Asian Islam.

\section{The Three Waves of Globalisation}

Let me identify and then explain briefly what these three waves of globalisation are. The first wave is what I call the Muslim-dominated globalisation. Its time-span of about 500 years extends from the beginning of the eleventh century until the beginning of the sixteenth century. Two historic events symbolise the end of the Muslim-dominated era of globalisation, the end of Muslim power in the Iberian Peninsula with the fall of Granada in 1492 and the fall of Malacca in 1511, a flourishing Muslim city-state and a regional power in Southeast Asia. The significance of the link between the two events is not easily lost. Granada and Malacca may be at opposite ends of the Muslim world, but in the words of a Southeast Asian scholar, the late Alijah Gordon, "the distance between Granada in 1492 and the 1511 Portuguese-Catholic aggression on Muslim Malacca is but the twinkling of an eye. With 1492 as a backdrop, we can understand the mentality of the Iberian Catholic Portuguese who were to devastate Goa, Melaka, and so on."

The second wave of globalisation extends from the beginning of the sixteenth century until the Second World War, a time-span of about 450 years. This is on the whole a Western-dominated globalisation but with a number of centres of Muslim power offering a fierce competition with mixed results. The beginning of the second wave coincides with the beginning of the Columbian era with the discovery of the New World followed by the creation and consolidation of the first world empire owned by the Spaniards and the Portuguese.

The wave heightened with the emergence of other European colonial powers and their subsequent rivalry often backed with military power for the control of monopoly trade, with Muslims usually caught in the cross fires. This is the age of globalisation of colonial economy, resulting especially in the globalisation of agricultural goods and the globalisation of people in the service of colonial economy. This globalisation of colonial economy went hand in hand with the globalisation of Christian faith. 
In the second half of the era under consideration, following the birth of the European consciousness with its idea of a single European civilisation, we saw the globalisation of Western ideas like secularism, modernism, nationalism and the nation-state, evolutionism, capitalism and communism. The period from the second half of the nineteenth century to the first half of the twentieth century also saw the globalisation of political Islam that sought to liberate Muslim lands under colonial rule. The second wave ends with the emergence of worldwide movements for national independence that led to the dismantling of colonial empires and the departure of Western colonial powers from their colonies as these colonies one after another became independent nation-states mostly after the Second World War.

The third wave is identified with contemporary globalisation, which is Americandominated. Contemporary globalisation is very much multi-dimensional in nature, and being American-led it is naturally dominated by the American global agenda. Various ideas dear to American society like democracy, civil society, human rights, have been globalised, inviting mixed responses from the non-Western world. But America has to deal also with unexpected and unwelcome developments in contemporary globalisation, namely the globalisation of terrorism, which many people have equated with the globalisation of anti-Americanism. The globalisation of terrorism does not deserve to be treated as a dimension of globalisation proper, since being destructive in nature it can only have the effect of slowing down globalisation, wiping out its virtues, and placing its future in doubt or in confusion.

The beginning of the third wave coincided with the birth of new nation-states that constitute the so-called Third World or developing countries. At the same time that these countries had to wrestle with the legacies of colonial rule, colonial economy and colonial administration, with many still not yet able to see light at the end of the tunnel, they were also caught in the global ideological battles between the West and the Communist Bloc. The Third World, including the Muslim World, finds itself having to come to terms with a new global reality in which America stands as the sole superpower following the fall of the Soviet Union.

Far from being a meaningful player in contemporary globalisation, the Third World, given the current stage of its economic and political development, finds itself very much a spectator or on the receiving end of this globalisation with even more disastrous consequences for its peoples' future than what they had experienced under colonial rule. No wonder some Third World leaders refer to contemporary globalisation as some sort of post-colonial colonialism under a new guise. After having led and experienced the first wave of globalisation guided by a global ethics founded on the spiritual teachings of the Qur'ān that affirm the civilisational goal of securing the common good of humankind, Islam may find itself increasingly consulted on how best to moderate contemporary globalisation in a way and in a direction that will be beneficial to humanity as a whole. 


\section{Islam and the Spirit of Globalism}

We may assert that there can be no globalisation without globalism. A global outlook and the spirit that sustains and enhances it is what I call globalism, the 'alamiyyah spirit. If Islam has been able in the past to unleash global forces of change for the betterment of humankind to the point of generating its own wave of globalisation, that is because of the spirit of globalism inherent in its teachings. There are many arguments in support of the claim that Islam is permeated with the spirit of globalism. But it is sufficient to cite three arguments for the purpose at hand. First, the Qur'ān addresses humankind many times on issues pertaining to their common good and their general welfare. ${ }^{9}$ Second, Islam believes in the idea of a worldwide supranational community that transcends ethnic and geographical areas. Third, the role of the religious institution of hajj and the twin cities of Mecca and Medina as permanent agents of globalisation, at least for the global Muslim community, cannot be overemphasised.

These three arguments also show that in principle Islam cannot be opposed to globalisation. On the contrary, it is through the realisation of globalisation that many of its social teachings find practical fulfilments. What Islam is opposed to is an unjust globalisation that does not contribute to the common good and the general welfare of the world community. Otherwise, Islam is completely on the side of globalisation.

\section{Southeast Asian Islam in the First Wave of Globalisation}

Southeast Asian Islam owes its origin and development into a regional force in the first wave of globalisation. It is not the purpose of my presentation to provide a detailed account of the spread of Islam in the region. What I am interested in, on the basis of known facts, is an understanding of the trends and processes and forces at work that form some kind of a regional pattern underlying the development of Southeast Asian Islam. Then we want to see whether or not this regional pattern bears some resemblance to a contemporary regional pattern found in another part of the world. In other words, we are interested to see whether or not the tendencies and forces at work were unique to Southeast Asia or more global in nature.

What has emerged from this study is the following general pattern. Islam came and spread to the Malay Archipelago through the twin forces of trade and missionary activity. Muslim traders came to the region from the Middle East via India as well as from China. The Archipelago lies on the ancient trade route between Arabia and China. Even in pre-Islamic times, the Archipelago had trade links with both Arabia and China and received their traders. After the birth of Islam, historical records mention the existence of early settlements of foreign Muslim traders in several maritime towns of the Archipelago at various points in time. Mentioned were the 
west coast of Sumatra (about $674 \mathrm{CE}$ ), and Kedah on the west coast of the Malay Peninsula and in Palembang in East Sumatra (878).

But from the eleventh century onwards, we notice a growing number of settlements of foreign Muslim traders that suggests a more intensified trade activity compared to earlier times. Clearly these traders have brought Islam to the region, although they were not necessarily engaged in the propagation of the religion among the local people. Apparently, some conversions did take place among the local commercial community as a result of their interactions with the foreign traders, including those with links to the Court.

The propagation of Islam was only noticeable after the arrival of missionaries around the middle of the thirteenth century. Historical records point to the existence of an organised missionary activity directed from Mecca. It was only after the arrival of religious scholars as missionaries, mainly Sufis, that we had the first conversion of a Malay ruler to Islam, apparently not long after their arrival. As a result of this Sufi missionary activity, the kingdoms of Perlak and Samudra situated in modern-day Aceh, Sumatra were converted to Islam, and the two were united to form the Muslim kingdom of Pasai, which appears to be the earliest centre of Islamic learning in the Archipelago. With the establishment of the first Malay-Islamic state in the second half of the thirteenth century, both trade and missionary activity gained a new momentum.

In the next two centuries, right to the time of the Portuguese conquest of Malacca in 1511, following more successes in missionary work, several more Malay sultanates came to be established. These include the sultanates of Brunei, Malacca and Pattani. The Brunei sultanate deserves a special mention since its realm extended to Manila prior to the arrival of the Spaniards. But in the period considered, it was Malacca that emerged as the most powerful and the most prosperous kingdom in the region. At its height, Malacca, which became Muslim in about 1414, was a global, cosmopolitan city-state with one of the world's busiest ports and with strong trade relations with China, India and the Middle East. It was also an intellectual centre attracting Arab, Persian, and Indian religious scholars and a regional centre for the propagation of Islam.

By the fifteenth century, Chinese Islam had come to participate in the Islamisation of the Archipelago, especially of Java. Chinese Muslims had come to the Archipelago as both traders and missionaries. They were an influential component of the cosmopolitan population in the principal towns of the Javanese Pasisir (northern coastal areas). According to a member of Admiral Cheng Ho's (Zhen He) naval expedition to the Archipelago in 1413-15, including visits to Java and Malacca, most if not all of the Chinese in the region were Muslims. So significant had been the contribution of Chinese Muslims to the Islamisation process in the region that there 
had even been claims of a 'Chinese-Muslim connection' with both the founding of the first sultanate in Java and the first Sunan Giri or the first saint of Java.

By the end of the fifteenth century, a large part of the Archipelago had been Muslim or come under Muslim rule. The Malay Peninsula, Champa and Patani to its north, the greater part of Sumatra, Brunei and some parts of Java had joined the ummah. In other parts of the Archipelago, Islamisation was being vigorously pursued. We have emphasised that the spread of Islam in the region was realised through trade and missionary activity.

A question to ask is why these two forces had become so important especially between the thirteenth and fifteenth centuries in influencing the trends and shaping the process of Islamisation in the region. Before answering this question, let us just consider briefly a contemporary phenomenon of Islamisation in another part of the world, namely the spread of Islam to sub-Saharan Africa. Apparently, trade again features prominently in the Islamisation of this region. By the tenth century, Muslim traders from North Africa had established a business presence in several commercial centres in the southern Sahara from which they carried out trade with other towns as far south as the capital of Ghana. By the eleventh century, Islam had spread in Mali, Senegal and Ghana. By the twelfth century, Ghana whose non-Muslim king used to invite Muslim traders to his capital became a powerful Muslim state. In the words of one scholar,

Muslims established trading centres that by the end of the fifteenth century reached the fringes of the forest. They created a commercial diaspora with a common religion, language, and legal system, the shari'ah, a personal and extraterritorial divinely ordained law, which added to the mutual trust among merchants. Conversion to Islam thus became necessary for those who wished to join the commercial network. ${ }^{10}$

However important was the role of traders as carriers of Islam in the sub-Sahara region as in the Southeast Asian experience, it was the religious scholars who were instrumental in Islamising its kings. The conversion of kings to Islam paved the way for further Islamisation of their respective kingdoms. The 1068 account of al-Bakrī, the Spanish Muslim geographer, that emphasises the important role of newly converted rulers at the hand of religious leaders in the process of Islamisation in various sub-Saharan African kingdoms, draws an interesting parallel with the Southeast Asian experience. In the fourteenth century, there emerged the powerful empire of Mali, which Ibn Batțuttah visited in 1352-53 during the reign of Mansa Sulayman, six years after he visited the Malay kingdom of Pasai, with Timbuktu turning into an advanced intellectual centre. It would be an interesting exercise to compare between the two contemporary cultures as observed by Ibn Bațtuțah, as part of our attempt to identify global trends in the contemporary Muslim world. 
Clearly, Islam was the central force in the globalisation of free trade. The importance of trade culture to Islam cannot be overemphasised. Pilgrimage was the main agent of this globalisation of trade, and in an expanding Muslim world, it was hajj that helped the most in integrating the newly added communities and regions into the global ummah. The pilgrimage routes and the trade routes were generally one and the same, each enhancing and strengthening the other. The globalisation of free trade went hand in hand with the globalisation of ideas and values based on spirituality and ethics. It gave rise to cosmopolitan societies and this raised the issue of the meaning and significance of pluralism. It was to Islam's credit that it was able to deal effectively with the issue. Malacca was the best example of a Southeast Asian cosmopolitan society of the times. Islam showed great respect for the rich pre-Islamic cultures of the region with Malay adat integrated into the shari 'ah as a source of law. Islam's philosophy of free trade is hostile to the idea of monopoly trade. This philosophy influenced the nature and character of regional trade that Islam had institutionalised in the region.

We may say that the 500-year encounter between the evolving Islam in the region and the various indigenous religions and cultures had given birth to a Southeast Asian Islam that was and still is generally open and tolerant. That Islamisation had been realised through trade and peaceful propagation of the religion was what primarily shaped the character of Southeast Asian Islam. By way of contrast, let me conclude our discussion of the first wave with the following quotation from Anwar Ibrahim's speech titled "Globalisation and the Cultural Re-Empowerment of Asia":

When the Portuguese first arrived in Malacca in the late 15th century, the Malays were fascinated with their strangely pink complexion, their build and their apparel. They crowded around these 'white Bengalis', examining their clothing, stroking their heads, even twisting their beards. The Bendahara Sri Maharaja, or Prime Minister, out of sheer goodwill compounded by naiveté, conferred the commander of the Portuguese ship robes of honor and adopted him as his son. Had the Portuguese come only to trade, history might have taken a different turn. But they wanted to dominate and control trade. And Malacca was too strategic to be left alone. ${ }^{11}$

Indeed history has its strange and unexpected ways! On 24 July 1511 Malacca fell to the powerful cannons of the Portuguese fleet. The author of the Malay Annals described the Portuguese military conquest in these terms: "And the Franks engaged the men of Malacca in battle, and they fired their cannons from ships so that the cannon balls came like rain. And the noise of the cannon was as the noise of thunder in the heavens and the flashes of fire from their guns were like flashes of lightning in the sky, and the noise of their matchlocks was like that of groundnuts popping in the frying pan." 12 Exaggerated or not, this is the Malay way of saying "the Portuguese inflicted an untold destruction of Malacca". 


\section{Southeast Asian Islam and the Second Wave}

Earlier, I identified the major landmarks associated with the second wave. What was the impact of the second wave on Southeast Asian Islam and what responses did it invite from the latter? Let us deal with its impact as well as with the responses which it invited but confined to the sixteenth century. Given the strategic importance of Malacca and its acclaimed position as the most powerful and the most prosperous Muslim state in the region, the Portuguese conquest was a major blow to the morale of Southeast Asian Islam.

Politically, the century marked the beginning of the decline of Muslim political power in the region in the sense that following the conquest, Southeast Asian Islam failed to produce another state that equalled or surpassed Malacca's brilliance. Not even Aceh at its height, Malacca's best successor, could achieve that. Economically, the Portuguese monopoly trade posed a grave danger to the Muslim-established regional trade infrastructure and network and 'common market'. For a while, this monopoly system drove many Eastern merchants from Malacca to such commercial centres as Brunei and Aceh, helping to increase their prosperity. But developments that were to follow in various parts of the Archipelago such as the arrival of the Spaniards in the Philippines in 1565 and the Dutch East India Company (VOC) the following century could only mean a trade war that would bring destruction to traditional Muslim trade.

Religiously, the coming of the Portuguese and Spaniards had checked the momentum of Islamisation. About half a century after its conquest, the Malacca that used to be the nerve-centre of the propagation of Islam in the region was turned into a Catholic city with 19 churches and chapels, including a cathedral, with Jesuits, Dominicans, Franciscans and secular priests serving some 20,000 Catholics. Perhaps, if the Spaniards had not arrived in the Philippines at the time they did, Islam would have spread over Luzon and the Visayas. In this armed confrontation, backed by religious images of the other, between the Iberians on one side and the Malay-Muslims on the other were sown the seeds of conflict in the region.

Both the Portuguese who captured Malacca in 1511 and the Spaniards who reached the Philippines in 1565 perceived their fight against the Muslims of Southeast Asia as a continuation of the reconquista they had waged against the Moors on the Iberian Peninsula. To emphasise this continuity of perception, they categorised the Muslims in Southeast Asia as Moors. This categorisation is what gave the name Bangsa Moro to the Muslims of the Philippines that have survived to this day. On their part, the Muslims considered it a challenge to their patriotism and Islamic faith. They also perceived Christianity as a militant religion since in their encounters with the colonial conquests they saw that the military and the religious were always working together as a single expedition. 
In response, Aceh fought what it perceived to be a jihād against Portuguese Malacca. In collusion with other Muslim states Aceh tried several times to recapture Malacca, but without success. In the second half of the sixteenth century, Aceh succeeded in securing technical military and naval assistance from Ottoman Turkey although not on the scale it had desired. Turkish military assistance including military personnel to Aceh alarmed the Portuguese. But remembering that it was the globalisation of its monopoly trade that it was primarily after, only when Aceh revived the Red Sea spice trade did the Portuguese seriously consider conquering Aceh.

Due to various reasons, the conquest plan never materialised until May 1606. The conquest expedition was, however, a failure. Aceh was saved partly by the tactical errors of the attacking force and partly by the Dutch action to besiege Malacca. The Malay-Muslim confrontation with the Portuguese not only produced the first $j i h \bar{a} d$ against a Western power known to the region but also gave birth to some sort of Malay-Islamic nationalism, which I regard as the prototype of modern Malay nationalism, centuries before the phenomenon of nationalism of the Western type.

The sixteenth century may be regarded as the beginning of an intense competition and rivalry between Muslim and Christian missionaries. Malacca and Manila had turned into centres of the propagation of Christianity in the Archipelago. Although the expansion of Islam in the Philippines had been permanently checked, Islamisation continued to make progress in the eastern islands of the Archipelago. Interestingly, the fall of Malacca had contributed to this further progress in Islamic propagation since many Malay-Muslim refugees and merchants had fled to these islands, settling in places like Makassar and Banda. While Islam made gains in Maluku, the Portuguese suffered a reversal there when Sultan Bāb-Allāh expelled them from Ternate in 1575.

The seventeenth century saw the rivalry, including religious, between the Iberians and the Dutch in Southeast Asia, an extension of their war in Europe. The rivalry was fundamentally economic, the pursuit of the monopoly of the spice trade. But the Malay-Indonesian Muslims also saw for the first time in their history intraChristianity religious feuds between the Catholic Iberians and the Protestant Dutch. In 1610, the Dutch established a trading post on the site of modern Jakarta. Iberian military power continued to weaken while Dutch power grew stronger. Malacca became Dutch in 1641 until it was handed over to the British through the Anglo-Dutch Treaty of 1824.

Through both wars and treaties with various Muslim centres of power, particularly in the Maluku, as well as the defeats of the Iberians at their hands, the Dutch using the VOC as their chief instrument succeeded in securing the monopoly of the spice trade. In the eyes of Muslims, however, these so-called treaties such as the Bungaya Treaty between the Muslim government of Makassar and the VOC signed in 1667 
were not mutually agreed but agreements enforced by strength of arms, and the VOC was hardly an innocuous trading company but a brutal instrument of colonisation.

The general Malay-Indonesian Muslim attitude toward the Dutch monopoly trade in the Archipelago may be best conveyed by this response of Sultan 'Alā' al-Dīn of Makassar in 1615 to Dutch insistence that they had a monopoly in Maluku and Makassar trade was forbidden there: "God made the land and the sea; the land he divided among men and the sea he gave in common. It has never been heard that anyone should be forbidden to sail the seas. If you seek to do that, you will take the bread from the mouths of people."13

By 1682, the VOC had succeeded in establishing complete control over Indonesian trade. In practical terms, however, by the turn of the century, the Dutch had institutionalised what must be regarded as a colonial policy embracing trade, political and religious matters in various parts of the Archipelago even while pursuing them in the name of doing trade. Not surprisingly, many Muslim leaders had strongly opposed these moves to the point of launching political and militant opposition. A case in point is Shaykh Yūsuf of Makassar. A prince, warrior, and Sufi, who had studied in Aceh, Shaykh Yūsuf was exiled to Cape Town, South Africa in 1694 with members of his family and a number of followers following his militant opposition to Dutch colonial policy in Makassar in particular. These exiled Malay-Indonesians had helped to found the first Muslim community in South Africa.

The eighteenth and nineteenth centuries saw the Dutch wage wars against the Muslim traditional centres of power, destroying them and creating new centres of power supportive of their attempts to secure a complete monopoly of trade throughout the Archipelago and also to facilitate the expansion of Protestantism. The destruction of the sultanates was almost complete such that only the Sultan of Hamengku Buwono had survived to remind Indonesians of their past. Formally, Indonesia only became a Dutch colony in 1799 with its handover from the VOC to the Dutch government. But the end of inter-European rivalry was not yet in sight when the British and the French entered the Archipelago scene in pursuit of their global colonial economy. Having attained the status of global powers with a global network of colonial interests, their conflicts also tended to be globalised. The Archipelago was very much affected by these global conflicts.

The British through the English East India Company helped to break up the Dutch monopoly of spice trade. The focus of their challenge to the Dutch monopoly was Penang, which they established as a colony in 1786 . From then on, it was a rapid expansion and consolidation of the British presence in the region with Penang followed by Singapore, Malacca and the rest of the Malay Peninsula and Borneo and other parts of the Archipelago. In 1811, British forces occupied Dutch territories in the Archipelago during the Napoleonic Wars. Five years later, these territories were returned to the Dutch. But the Anglo-Dutch Treaty of 1824 drew the spheres 
of influence of the two colonial powers in the region thus laying down the national boundaries that separate modern Indonesia and Malaysia.

The last two and a half centuries of the second wave have another major significance for the region. This is the globalisation of people induced by the globalisation of colonial economy. The British encouraged or forced the migrations of millions of ethnic Chinese from China and ethnic Indians from India, including Sri Lanka to its territories in Southeast Asia, particularly Malaya to serve their controlled tin and rubber industries and as workers to build infrastructures for the fast growing colonial economy as well as petty businessmen. These migrations were to have major political, economic and cultural consequences for the former British territories. But there were also migrations, more often than not forced, from the region to other parts of the world with colonial links with Britain and the Netherlands. Globalisation of people and colonial economy during this period thus helped to create a worldwide Malay Diaspora practically in every continent. Today, there is a half-million strong Cape Malays community in South Africa, whose founder, Shaykh Yūsuf of Makassar was hailed by Nelson Mandela as a symbol of freedom against apartheid at the 300th anniversary of the coming of Islam to South Africa. In Surinam in South America the Malay-Indonesians form about 15 per cent of the population, and there are also Malay and Indonesian communities in Britain and the Netherlands.

Then, there is the impact of the globalisation of ideas of the period on the region. In the last half a century prior to the Second World War, there were three major political ideologies that had a great impact on Southeast Asian Islam. These were political Islam mainly associated with the reformist-modernist thought of Jamāl al-Dīn al-Afghani and Muhammad 'Abduh, secular nationalism, and communism. During this most intense period of the struggle against colonial rule, it is understandable why ideas on nationalism have a great appeal to particularly Muslims. Islamic, secular, and communist nationalism had their respective constituencies, and they competed actively for political influence. But it was Islamic nationalism that commanded the greatest following in both Malaysia and Indonesia.

The three ideologies continued to compete with each other for political support and influence after independence. The coming of Islamic reformist thought, secularism, and communism to the region produced mixed responses. Proponents of religious reform founded the Muhammadiyah movement in Yogyakarta in 1912, which has grown to become Indonesia's second largest Muslim organisation with more than 10 million members. The Muhammadiyah movement also existed in Malaysia and Singapore with lesser influence in the former. The organisation's core activity from which it derives its main strength is education.

The Muhammadiyah and other phenomena like the Ahmadiyah movement considered heretical by the majority of Muslims - and the appeals of secularism 
and communism invited a major response from the traditionalists, who decided to establish the Nahdatul Ulama (NU) in 1926. The NU today with a membership of about 40 million and previously headed by the former President of Indonesia, the late Abdul Rahman Wahid, is the biggest Muslim organisation in the world. In line with its traditionalist thought, it has opposed various kinds of ideas that had penetrated Indonesian society, including secular nationalism, communism, the Muhammadiyah's religious reformist thought, and Wahhabism.

\section{Southeast Asian Islam and the Third Wave}

The third wave of globalisation confronts Southeast Asian Islam with the post-colonial political realities. The region became a battleground of various political ideologies originating from the West. Islam in the region had to respond to the ideologies of nationalism, capitalism, and communism. In the Malay context, nationalism always means regionalism. The spirit of regionalism runs deep in the veins of the Malays. The Malay word Nusantara, referring to the Archipelago, means literally 'inter-lands' or 'inter-nations' and embodies the idea of a network of islands. The word also implies the idea of freedom. Regionalism is the natural worldview of the Malays. In a sense, Sultan 'Alā' al-Dīn invoked the spirit of Nusantara when he opposed the Dutch monopoly trade. The physical reality of the Nusantara made the Malays believers in free trade, and when they became Muslims Islam provided and strengthened the dimension of justice in their notion and practice of free trade. At the political level, nationalists of all ideological persuasions have always organised their respective constituencies at the Nusantara level. Whether they wanted to establish dār al-islām (Islamic state), a communist state, or a secular non-communist state, in both theory and practice they were concerned with such a state in the context of the whole Nusantara, ignoring not only artificial physical boundaries created by the colonial powers but also religious boundaries. To the Malay nationalists, Jose Rizal, executed by the Spanish colonial authorities in 1896, was as much a nationalist hero to the Catholic Filipinos as to the Muslim Malay-Indonesians in the rest of the Archipelago.

This spirit of regionalism survived colonial rule. Thus there was the postindependence attempt by Sukarno, Macapagal and Tunku Abdul Rahman to form 'Maphilindo', some sort of union between Malaysia, Indonesia, and the Philippines. But it was too much to expect the proposal to succeed when the three leaders were separated by a vast distance of political ideologies. But at least the attempt showed one thing. The traditional spirit of regionalism survived. There were other attempts. The Association of Southeast Asia (ASA) proposal did materialise, and the resulting entity became the nucleus of the future ASEAN. 
Southeast Asian Islam did have to confront the ideological challenge posed by communism. Indonesia nearly became communist but with its victory over it Islam grew in political strength and influence. With the newfound democracy and political freedom, Islamic discourse in the post-Suharto era brought to the fore all shades of religious opinion. The present period is in a sense still a transition, and like all transitions, it can only be fluid. But we should not be fooled by this seemingly fluid situation. Underneath, visible as well, are stabilising elements that offer hope to Indonesia. The idea of the Islamic state is a powerful global idea among Muslims. It is only natural to expect proponents of the idea asserting their Islamic political views and agendas in the largest Muslim nation on earth. In Malaysia as well, Islam was mobilised to counter communism and in the process gained opportunities for asserting itself. We may say that, on the whole, Southeast Asian political Islam had triumphed over other political ideologies.

At the conceptual level, Southeast Asian Islam has the capability to deal with the various ideas that are currently globalised. Islam has the inner resources to provide a positive response to such ideas as democracy, human rights including women's rights, civil society and free trade. In the case of Southeast Asian Islam, these issues have passed from the conceptual stage to the practical stage. The issue is no longer whether Islam is compatible with democracy or not. Malaysia has been practising democracy since 1955 . The real issue is how it can be more democratic, and within the framework of Islam itself there is still so much space for the expansion of democratic values. To the surprise of many people Indonesia today is practising a vibrant democracy. The same situation applies to the other so-called Western-originated ideas.

\section{Conclusion}

Let me conclude by saying that as far as Islam is concerned it is not the idea of globalisation that is at fault or problematic. Islam is pro-globalisation. From the perspective of Southeast Asian Islam, in a sense, on a grander scale, the whole of the world is Nusantara that speaks for a free and just trade. But the current manifestations of global trade exhibit many unjust elements, which Islam abhors. Even Mahathir Mohamad, the controversial former Malaysian leader, is not antiglobalisation, despite his anti-West rhetoric. He is merely against what he and many Muslims perceive as the injustices of current globalisation. The civilisational goal of Islam is the globalisation of the common good for all nations, not just what is perceived to be good by one or two nations. In the Islamic perspective, the essence of free trade is the globalisation and sharing of wealth. In the words of the Qur'ān (59:7), "wealth should not only circulate between the rich amongst you". 
This article suggests the following policy proposals:

- Globalisation should be open to different interpretations and contextualised within historical developments that also allow space for civilisations other than the Western.

- Islam has from its outset maintained the spirit of 'alamiyyah and globalism on humanity, its common predicament and shared space on the planet earth.

- The civilisational goal of Islam is globalisation of the common good of all nations, not only the most powerful few among them.

- Muslim leaders and intelligentsia have opposed globalisation, not because they object to globalisation as such, but because the current manifestations of globalisation exhibit many unjust elements, which are deemed unacceptable.

\section{Notes}

1. This article is largely based on the so far unpublished Malaysia Chair of Islam in Southeast Asia Public Lecture which I delivered in 2002 at the Prince al-Waleed Center for Muslim-Christian Understanding, the Edmond Walsh School of Foreign Affairs, Georgetown University, Washington DC.

2. Many scholars of contemporary Islam now realise that the term 'Islamic world' has become problematic. Muslims in the post-colonial period live in nation-states, some of which they rule and in which they are majorities, and others in which they are minorities living under non-Muslim rule. If by the 'Islamic world' we mean the group comprising of only Muslim majority and Muslim-ruled nation-states, then we have to exclude from that world about 550 million Muslims or about a third of the world's Muslims. But it would be absurd to make such an exclusion. Realising the problematic nature of the term 'Islamic world' with practical implications for its membership, the Organisation of the Islamic Conference (OIC) adopted the policy of admitting into its membership large or strategically important Muslim minorities. The term 'global Muslim ummah' appears to be better suited for the purpose at hand. For a more detailed discussion of the problematic nature of the term 'Islamic world' and the options to take so as to escape from the dilemma, see Osman Bakar, "Dialogues of Civilisations After 9/11 with Specific Reference to the West-Islam Cultural Divide: Promises and Obstacles", Katha. Journal of the Centre for Civilisational Dialogue [Kuala Lumpur, University of Malaya] 3, no. 1 (2007), 19-30.

3. The region can boast among other things to have the most populous Muslim country in the world, namely Indonesia, Malay as one of the most widely spoken Muslim languages, and to have Malaysia with the longest uninterrupted run of democratic rule among Muslim countries as well as with the record of being one of the largest trading nations in the world.

4. I am quoting here what appears to be the most common understanding of the term 'globalisation'. The quoted definition of globalisation is used by Princeton N. Lyman, a contemporary scholar of globalisation. While acknowledging the definition as a popular one, Lyman also makes the point that the phenomenon of globalisation could not be limited to trade and financial flow since "there are other trends driven by the same explosion of technological capability that have facilitated the financial changes". In his view, "globalisation of communications is one such trend". See Princeton N. Lyman, "Globalisation and the Demands of Governance", Georgetown Journal of International Affairs 1 (Winter/Spring 2000), 90.

5. For more details on this extremely important intellectual agenda of the Institute see Mohammad Hashim Kamali, Civilisational Renewal: Revisiting the Islam Hadhari Approach (Shah Alam [Malaysia]: ARAH Publications, 2008). 
6. There do exist political, economic, and cultural histories of Southeast Asian Islam, however, to the best of my knowledge, no work has ever appeared on its civilisational history, especially on the basis of a study of the impacts of modern and pre-modern globalisations on the region as I propose to do in this article.

7. In 2011, the Malay-Indonesian world will remember the 500th anniversary of the fall of Malacca at the hands of the Portuguese. From the point of view of the civilisational history of Islam in general, and Southeast Asian Islam in particular, the fall of Malacca - coming so soon after the fall of Granada - was a major event with manifold implications for the global ummah.

8. See Alijah Gordon (ed.), The Propagation of Islam in the Indonesian-Malay Archipelago (Kuala Lumpur: Malaysian Sociological Research Institute, 2001), xii.

9. There are more than 25 verses in the Qur'ān which begin with a call to the whole of humankind. These verses deal with a wide range of issues that are now of global importance to humanity.

10. See Nehemia Levtzion, "Islam in Africa to 1800", in: John L. Esposito (ed.), The Oxford History of Islam (Oxford: Oxford University Press, 1999), 476-7.

11. See Anwar Ibrahim, "Globalisation and the Cultural Re-empowerment of Asia", in: Joseph A. Camilleri and Chandra Muzaffar (eds), Globalisation: The Perspectives and Experiences of the Religious Traditions of Asia Pacific (Petaling Jaya [Malaysia]: International Movement for a Just World, 1998), 2.

12. Quoted in ibid., 2.

13. Gordon, The Propagation of Islam in the Indonesian-Malay Archipelago, 251. 